\title{
29. STRUCTURE AND SEDIMENT DISTRIBUTION IN THE NORTHWEST CORNER OF THE WEST PHILIPPINE BASIN
}

\author{
D. E. Karig, Department of Geological Sciences, Cornell University, Ithaca, New York \\ and \\ J. M. Wageman, Gulf Research and Development Company, Pittsburgh, Pennsylvania
}

\section{INTRODUCTION}

It is becoming increasingly clear that the West Philippine Basin displays abnormally complex tectonism, resulting from the effects of several types and ages of deformation. Reconstruction of the basin history requires that these deformations and their effects be separated and understood individually. One of the logical ways to approach this problem is to investigate those areas where the deformational zones intersect or overlap.

The northwest corner of the basin is one such area, where the Central Basin Fault appears to intersect the Luzon arc and is in turn covered by a large sediment apron which appears to postdate a period of subduction occurring along the eastern flank of the arc (Karig, 1973). Although no deformation of the apron sediments is observed, the insular slope to the south is the site of a recent subduction zone which may be extending itself northward (Fitch, 1972; Karig, 1973).

The recognition of the region's tectonic importance led to a rather intensive survey program during the Western Pacific geotraverse of the NOAA Ship Oceanographer. Seismic reflection, magnetic, and gravity profiles were collected along satellite-controlled track lines (Figure 1). Also available since the earlier reconnaisance study (Karig, 1973) are satellite-navigated profiles from V-21 and V-24 cruises of LDGO, Tasaday 5 of SIO and the DSDP Leg 31. The previously available data were incorporated and reanalyzed after being adjusted to the satellite-controlled tracklines.

The study began as an attempt to locate the northwestern end of the Central Basin Fault and to investigate its behavior at the basin margin. A major obstacle confronting such an endeavor is that the delineation of basement ridges in marginal basins is nearly impossible without detailed surveys, because the usual track spacing is several times the topographic wavelength. However, in the turbidite-fed apron adjacent to Luzon, the sediments were ponded and dammed between ridges, and because these ponds lie at different depths, the ridge correlation becomes relatively easy. Therefore, rather reliable contours were drawn at small intervals over the apron, but no new contouring was attempted elsewhere. These new data also permitted the better delineation of channels feeding the sediment apron, which in turn had significant implications for the late Tertiary tectonism of northern Luzon.

\section{DATA AND DISCUSSION}

The youngest major geologic feature in the region is the large sediment apron which extends northeastward from sources in northeast Luzon. Controlled in large part by basement topography, the apron represents submarine sediment transport exceeding $500 \mathrm{~km}$, and substantially more along the trough which lies at the foot of the Palaui Ridge (Figure 1). A second major sediment body lies west of the Palaui Ridge but this area was not studied in any detail.

The main apron is presently fed by the Cagayan River and submarine canyon, which drains most of northern Luzon, and probably also receives much smaller contributions from short streams on the east coast. Sediment thickness in the apron exceeds $2 \mathrm{~km}$ near the base of the island slope and along much of the trough next to the Palaui Ridge (Figure 2).

Internal geometries of the sediment bodies, as interpreted from seismic reflection profiles, are almost completely those of laterally transported, turbidity-type deposits. Beneath the turbidites near Site 293 indications of a basal pelagic section can be seen on reflection profile (Site 293, this volume), and it is likely that basal pelagic sediments exist beneath most of the basin. Sequences of reflective and transparent units are observed on most profiles, but cannot be easily correlated because the basement troughs which comprise the apron have quite different acoustic sections.

Limited available piston core data (Lair and Sanko, 1969) and both 3.5 and low-frequency reflection profiles indicate that coarse-grained turbidites are being deposited in the northern area and in the trough flanking the Palaui Ridge, and that much finer grained, almost hemipelagic-appearing turbidites are collecting elsewhere. For several hundred kilometers beyond the distal edges of the apron, the pelagic brown clay shows a high silt content (Lair and Sanko, 1969) and develops thicknesses over 200 meters, or nearly twice the norm in the West Philippine Basin.

Despite the variation in stratigraphic character in the apron, there does seem to be a widespread development of very reflective unit in the uppermost few hundred meters and an equally widespread underlying transparent layer which also has a turbidite geometry. This pair of units has been interpreted (Site 293, this volume) as reflecting an early deposition of fine terrigenous material following the demise of a subduction zone, in turn followed by more rapid collection of coarser material caused by the late Pliocene uplift of Luzon (Durkee and Pederson, 1961; Christian, 1964).

Surficial variability of sediment type seems closely coupled with the development of canyon-fan channel systems. Presently active and dominating the feeders is the Cagayan system (Figure 1). After travelling across the shelf north of Luzon in a number of small channels 


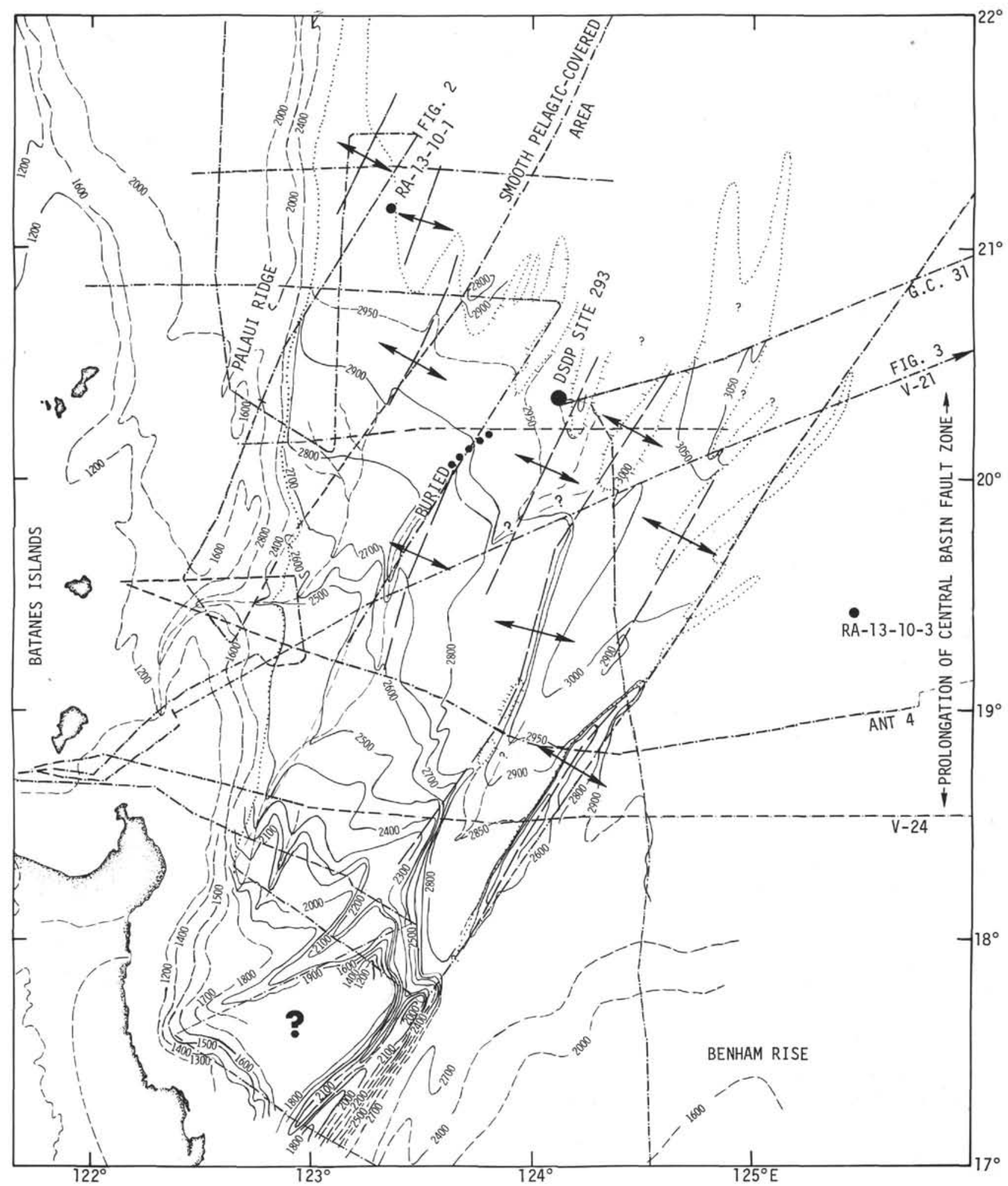

Figure 1. Revised bathymetric map of the sediment apron area northeast of Luzon in uncorrected fathoms. Stippled border indicates the edge of the turbidite apron. Channels are shown by heavy dots and ridge trends by heavy anticline symbols. The location of profiles shown in Figures 2 and 3 are shown by heavier track lines. 


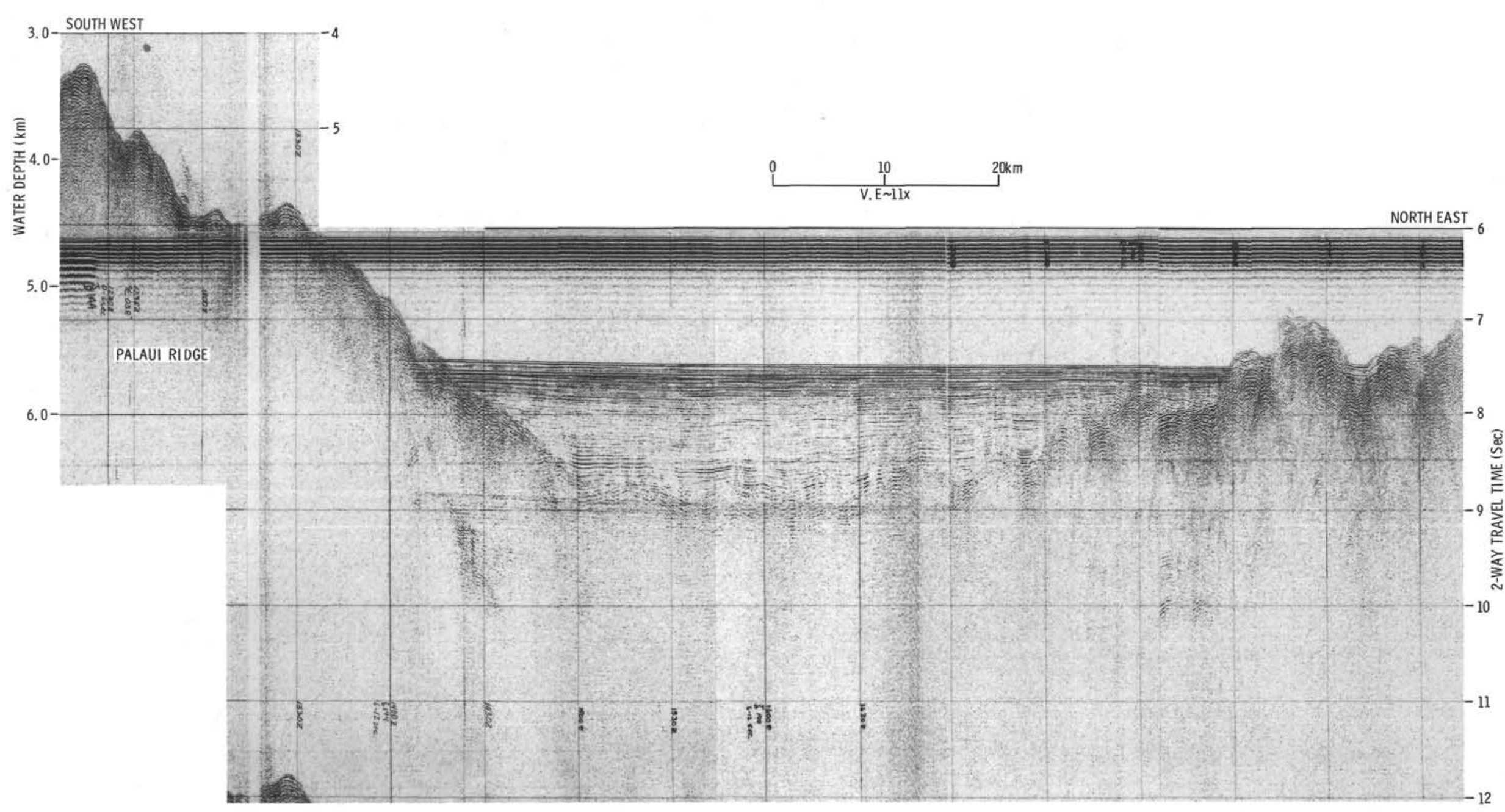

igure 2. Seismic reflection profile from NOAA ship Oceanographer across trough forming the northend of the sediment apron. This profile shows trough sediments lapping onto the Palaui Ridge and gives an indication of more than $2 \mathrm{~km}$ of trough sediments. 
(Figure 1), the system cuts through the Palaui Ridge in a deep canyon and can then be traced northward as a fan channel until it develops a large suprafan complex (Normark, 1974) which primarily feeds the trough along the base of the Palaui Ridge. Because of the damming effect of intervening basement ridges, little of this sediment would appear to reach the area where Site 293 was drilled.

Another well-developed fan channel can be observed to the east (Karig, 1973, and Figure 1) which can be traced with reasonable confidence from near the base of the island slope to about $19^{\circ} 30^{\prime} \mathrm{N}$. Despite the large size of the channel near $19^{\circ} \mathrm{N}$ (Karig, 1973), there is no sign of a distributary system nor a correlatively large river system and canyon. This channel may connect to one of several poorly delineated but small canyons along the Luzon coast between $17^{\circ} 20^{\prime}$ and $18^{\circ} \mathrm{N}$, but there are presently no significant streams draining into this coast. Thus, the large channel, without associated large source deviates from the general correlation of these two parameters (Normark, 1974). One solution is that this system is now inactive, that the sediment supply source has been shifted to the presently active system, and that the distributary system of the eastern system has been buried by sediment from the Cagayan system.

Still other, less persistent and less distinct channels occur southeast of the two larger systems. These cannot be traced toward Luzon, partly because of lack of data and partly because they cannot be distinguished from other morphologic features. If the degree of preservation can, in this situation, be correlated with age, then the channel systems would be progressively older toward the south and east.

The change in apron levels across basement ridges, observed on several profiles (Figure 3) initially suggested recent faulting, but more closely spaced lines indicate instead that the different sediment levels are a result of confinement of turbidites to troughs between the ridges. Evidence of recent faulting on the apron is lacking, but cannot be entirely dismissed because to the south along the east coast of Luzon there is very good evidence of a developing subduction zone (Fitch, 1972; Karig, 1973; Karig and Sharman, in press). An active trench can be traced to about $17^{\circ} \mathrm{N}$, but cannot be differentiated from the ridge-trough topography abutting the insular slope on the more northerly crossings. How the subduction attenuates northward remains to be determined.

The strongly lineated basement beneath the apron must have originated before the apron formed, in the mid-Tertiary or earlier, and could represent either original basin topography or the effects of later tectonic disruption. All the ridges and troughs trends between $\mathrm{N} 15^{\circ} \mathrm{E}$ and $\mathrm{N} 30^{\circ} \mathrm{E}$ except for the trough bordering the Palaui Ridge, which is probably or a different, subduction-related origin. Relief of the north-northeasttrending structures averages near $1 \mathrm{~km}$ and ranges to greater than $2 \mathrm{~km}$. Some of the larger ridges along the southeast border of the apron can be traced for 175 to $250 \mathrm{~km}$.

There are adequate data to conclude that no northwest-trending features which might be attributed to the Central Basin Fault extend into the apron area. Areas of smooth basement in the vicinity of $21^{\circ} \mathrm{N}$ to $22^{\circ} \mathrm{N}$ and $124^{\circ} \mathrm{E}$, and $19^{\circ} \mathrm{N}, 125^{\circ} \mathrm{E}$ to $126^{\circ} \mathrm{E}$ preclude the tracing of a major fault zone to either side of the apron. This, coupled with the recognition that the Central Basin Fault consists of north-south-trending ridges and troughs in several areas along its trace (Karig, this volume), suggests that the north-northeast trending basement topography beneath the apron is a splayed continuation of that fault zone. Rather than representing a spreading rise or major transcurrent fault, this zone of en echelon character seems to mark a rather

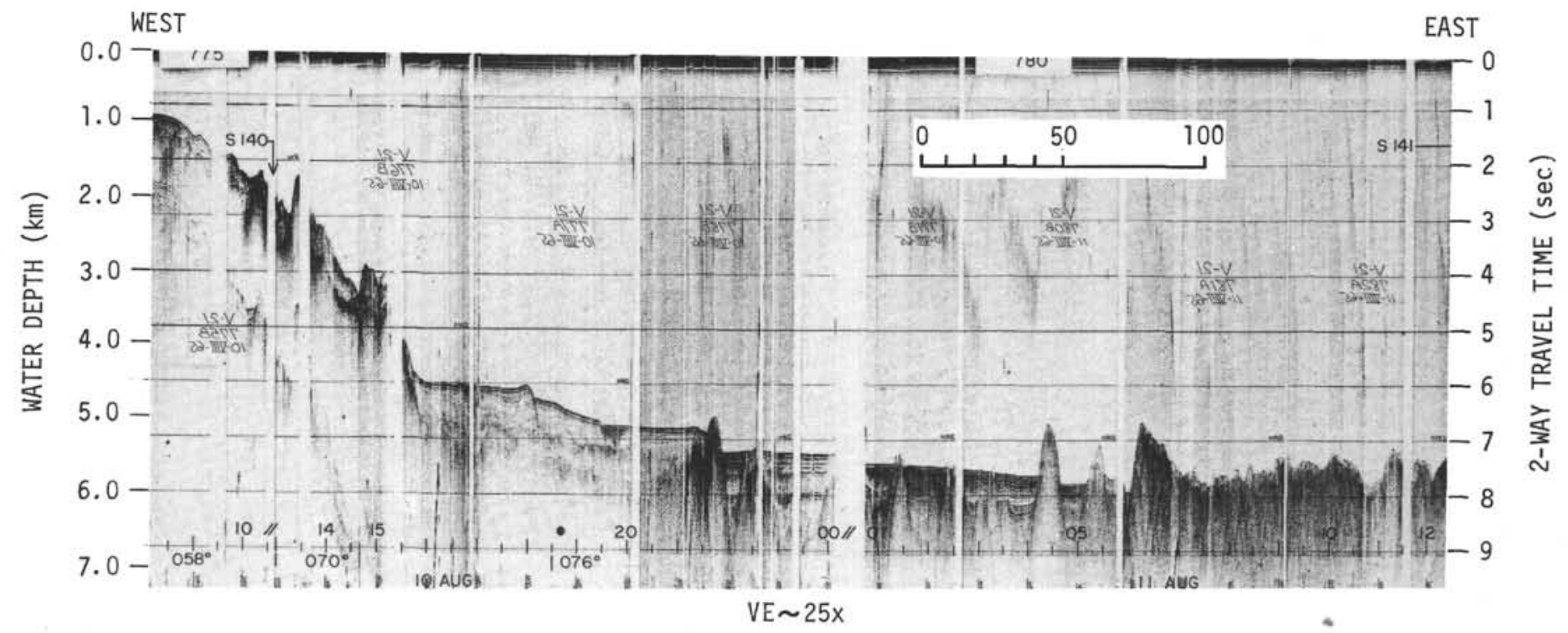

Figure 3. Vema 21 (LDGO) seismic reflection profile across the sediment apron northeast of Luzon. Ponding of sediments at different levels behind basement ridges and variations of acoustic stratigraphy across the apron shows well on the profile. 
modest amount of right lateral, distributed shear or east-west extension. If this is correct, then the problem of why the Central Basin Fault has not displaced the Palau-Kyushu Ridge disappears. The timing and tectonic significance of the fault zone are as yet unknown.

Several indicators suggest that this relief represents disruption of a basin crust well after its creation. Perhaps the most compelling is the occurrence of amphibolitic grade highly sheared igneous rocks beneath the apron sediments at Site 293. Either these rocks were uplifted by normal faulting or lie on transform faults. The short wave length of the north-northeast-trending topography, its persistence over much of the western part of the basin and the apparent exclusion of other trends rules against a transform interpretation.

Basal pelagic sections over several ridges can be observed but occur only on one flank, suggesting that the other flank is a normal fault system (Site 293, this volume) and that the ridges are tilted fault blocks. These ridges are larger and more persistent along strike than those generally observed in actively spreading marginal basins, which might suggest a different origin.

The north-northeast basement trend can be traced southward past the Benham Rise and eastward to the Central Basin Fault. On the Benham Rise, at least, the largest ridges are pre-late Eocene in age, and there is no evidence for significant faulting of the pelagic cover (Site 292 , this volume). There is a chance therefore that an original north-northeast lineation was generated with the crust and reactivated by later tectonism in some areas.

Miocene to Pliocene discoasters mixed into the slumped tectonic basement breccias and Miocene(?) apron sediment overlying basement in Hole 293 place an upper bound on the age of deformation. If motion on the Central Basin Fault, which also consists of northnortheast to north trending subunits, is a related event, then displacement is post Eocene (Site 290, this volume). The lack of tilting in the deeper turbidites over the ridge flanks argues that faulting terminated before much of the apron developed.

The northeast-trending basement lineations appear to be truncated by the eastern edge of the Palaui Ridge which trends north-south. Either the development of the Palaui Ridge postdated the faulting in the basin or else there was some type of plate boundary between them. There is no displacement along the boundary at present or during the growth of most of the apron (Figure 2).

At the boundary between the ridge and the basin, there is a linear basement trough, masked by more than $2 \mathrm{~km}$ of sediment, but over $7.5 \mathrm{~km}$ deep. Undoubtedly a part of the anomalous depth is attributable to sediment loading, but the sharp break into the trough on the east flank, and the still greater than $7 \mathrm{~km}$ basement depth at the narrower, fractionally filled northern end demonstrate the trench-like nature of this feature.

A change in the character of the sediment reflectors in the trough occurs at about $1.5 \mathrm{sec}$ at the south end and $0.5 \mathrm{sec}$ at the north end. The sediments above this break are contiguous with and assumed to be part of the sediment apron. The deeper sediments form a more reflective unit showing slight deformation. These are possibly the last trench wedge sediments, deposited in a dying subduction zone along this boundary (Karig, 1973).

Both the gravity and magnetic profiles of the Oceanographer support the idea that the Palaui Ridge consists of deformed sediments and forms a trench slope break of an inactive subduction zone. The nearly characterless magnetic profiles across the ridge require a very low remnant magnetism and susceptibility. In comparison, profiles across the Palau Kyushu Ridge, a remnant arc in a similar geometric and magnetic field situation, have anomaly amplitudes of several hundred gammas, which can be attributed to volcanics of andesitic and basaltic composition.

The gravity field over the Palaui Ridge area is similar in shape and position to those over active subduction zones, but with slightly subdued amplitudes (Figure 4; Watts and Talwani, 1974). A very large high, which is in part attributable to edge effects, occurs over the Batánes Island Ridge, where uplifted Tertiary limestone and volcanics and recent volcanism are displayed. A low over the basins to the east is bisected by a relative high over the Palaui Ridge. Simple calculations and comparison with gravity profiles (Caputo et al., 1964) over the Palau-Kyushu Ridge demonstrate that these anomalies are not primarily topographic or deeper crustal edge effects along the insular slope. Lack of constraining data prevents useful gravity modelling, but if the Palaui Ridge is approximated by a two-dimensional triangular prism superimposed, together with the flanking sediment fill, on a downbowed ocean crust, the 100-150 mgal crestal anomaly attributed to this ridge (Figure 4) implies an average ridge density significantly less than $2.7 \mathrm{~g} / \mathrm{cm}^{3}$. Despite its low accuracy, this exercise does implement the argument that the ridge is composed of deformed sedimentary material.

\section{CONCLUSIONS}

Perhaps the biggest surprise evolving from this study is that there does not appear to be any northwesttrending topography associated with the Central Basin Fault in the northwestern corner of the West Philippine Basin. It is most likely that the north-south trends in the surveyed parts of the fault zone resulted from the same activity which produced the large basement ridges east of Luzon. This deformation occurred between the late Eocene and late Miocene.

Because the basement lineations do not affect the Palaui Ridge, and because that feature is identified as part of an inactive subduction zone, the basement deformation seems to have occurred before cessation of subduction. The subduction episode remains poorly bounded by geology on Luzon as pre-mid-Miocene (Karig, 1973). Crust as old as Late Cretaceous was possibly subducted because pelagic foraminifera of that age were fed to the apron and recovered at Site 293 (Site Chapter, this volume).

Migration of the apron-feeding channels northward with time appears to be related to the uplift history of the Sierra Madre Range. The large abandoned channel which heads into the structural low in the range most likely once drained the Cayagan River through that gap. 


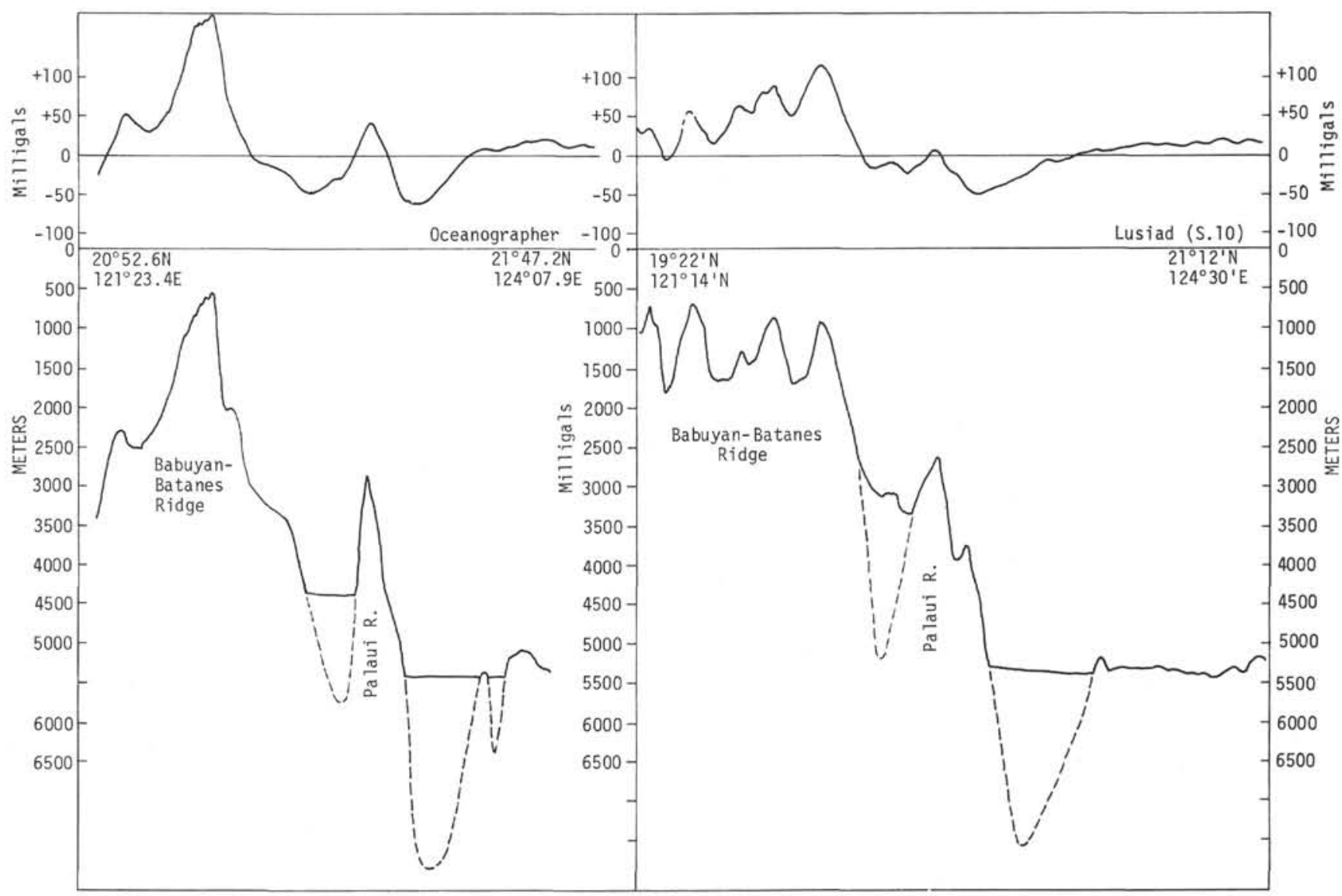

Figure 4. Bathymetric and gravity profiles across the Batanes-Palaui ridge-trough couple showing island arc-like character. Depth of sediment in the two troughs flanking the Palaui Ridge is estimated from Oceanographer reflection profiles. Gravity is from Lusiad cruise.

Continuing uplift of that section of the range probably forced the river northward, over the Sicallao basement ridge. This uplift was part of the general, large-scale uplift of northern Luzon operative since the late Pliocene, but its cause is not clear. No collision during that age span has occurred along this section of the arc. Subduction has been occurring along the western side of the island since at least the late Miocene so that uplift of the Sierra Madre seems to reflect a different process. One possibility is that, associated with preceding the northward propagation of the new subduction zone along the east coast, there is uplift of the future upper plate region.

\section{REFERENCES}

Caputo, M., Masada, R., Helfer, M., and Hoger, C. L., 1964. Gravity measurementsin the Atlantic, Pacific, and Indian oceans: May 1962-Aug. 1963 (R/V Argo): Interim Rept., Inst. Geophys. Plan. Phys. Univ. Calif., no. 7.
Christian, L. B., 1964. Post Oligocene tectonic history of the Cagayan basin, Philippines: Philippine Geol., v. 18, p. 114147.

Durkee, E. F. and Pederson, S. L., 1961. Geology of Northern Luzon, Philippines. Am. Assoc. Petrol. Geol. Bull., v. 45, p. 137-168.

Fitch, T. J., 1972. Plate convergence, transcurrent faults and internal deformation adjacent to southeast Asia and the western Pacific: J Geophys. Res., v. 77, p. 4432-4460.

Karig, D. E., 1973. Plate convergence between the Philippines and the Ryakya Islands: Marine Geol., v. 14, p. 153-168.

Karig, D. E. and Sharman, G. F., III, in press. Subduction and accretion in trenches: Geol. Soc. Am. Bull.

Lair, C. and Sanko, P., 1969. Core analysis and bottom photographs: Marine Geophysical survey program 65-67, Area 13, v. 5: Washington (U.S. Naval Oceanographic Office).

Normark, W. R., 1974. Submarine canyons and fans valleys: factors affecting growth processes of deep sea fans. In Modern and ancient geosynclinal sedimentation, Proc. Conf. U. Wisc. Nov. 1972.

Watts, A. B. and Talwani, M., 1974. Gravity anomalies seaward of deep-sea trenches and their tectonic implications: Geophys. J. Astron. Soc., v. 36, p. 57-90. 